\title{
THE EVALUATION OF SANITARY-EPIDEMIOLOGICAL SERVICE CONDITIONS ON A SUBMARINE
}

\author{
Michał Żychliński, Piotr Siermontowski, Romuald Olszański \\ Maritime and Hyperbaric Medicine Department, Military Institute of Medicine, Gdynia
}

\section{ABSTRACT}

Service on a submarine is the most stressful and psychologically challenging form of military service. It is characterised by specific living and sanitaryepidemiological conditions which are far from typical.

This work is based on the analyses of reports formulated from research conducted by a working environment laboratory, and on the control protocols of the sanitary supervision and control team (WOMP) Gdynia, from the Kobben submersible vessels in the years 2014 and 2015 . Military Centres of Preventive Medicine hold supervision over Military Units pursuant to generally applicable regulations in the civil environment and standardised NATO norms. Measurements concern the level of noise, mechanical vibrations, chemical agents, electromagnetic radiation, physiochemical and biological water and kitchenware tests. The objective of the research is to evaluate the service conditions on a submersible vessel with regard to sanitary-epidemiological aspects such as exposure to infectious and occupational diseases.

In selected stations, the conducted measurements indicate an increased level of noise, electromagnetic radiation and excess quantities of bacteria colonies on kitchenware.

Keywords: working environment, submarine, electromagnetic radiation, noise, vibrations, chemical agents

ARTICLE INFO

PolHypRes 2017 Vol. 57 Issue 1 pp. 51 - 62

ISSN: 1734-7009 elSSN: 2084-0535

DOI: $10.1515 /$ phr-2017-0031

Pages: 12 , figures: 1 , tables: 6

page www of the periodical: www.phr.net.pl

Publisher

Polish Hyperbaric Medicine and Technology Society

\section{Original article}

Submission date: $\mathbf{1 2 . 0 6 . 2 0 1 6 r}$.

Acceptance for print: 27.02.2017r. 


\section{INTRODUCTION}

Seafarers, serving in atypical conditions, are exposed to different hygiene and epidemiological hazards as compared to a regular environment. This is connected with the risk of an occurrence of infectious or occupational diseases in the course of service or upon its completion. Service on a submersible vessel is one of the most stressful and psychologically challenging forms of military service. A submarine constitutes an enclosed, ventilated space with variable temperature and humidity. The temperature inside the hull varies from 15-27 degrees Celsius, whereas humidity from 40 to $70 \%$ [1].

Such service involves certain sacrifices, namely: a small social and working area, disruption of circadian rhythm, overpopulation, a lack of the possibility to escape, isolation from the external world and an incapability to contact relatives. These factors are further extended by stress connected with working on costly equipment, in conditions which are far from 'normal'.

Military Centres of Preventive Medicine conduct sanitary-epidemiological supervision over units' subordinate to the Minister of National Defence. Military Units in the Pomeranian and West-Pomeranian provinces, including units of the Navy, fall under the jurisdiction of the Gdynia Centre.

Military Centres of Preventive Medicine hold supervision over Military Units pursuant to generally applicable regulations in the civil environment, and standardised NATO norms. The documents in question are the Regulation of the Minister of Labour and Social Policy as of 18 December 2002 (with regard to detailed principles on permanent or long-term bodily harm, procedure of determination of such a harm and procedure concerning payment of a one-off compensation) and the Regulation of the Minister of Labour and Social Policy as of 29 November 2002 (with regard to the highest permissible zones and levels of harmful agents in working environments).

NATO norms STANAG 1379 and STANAG 2345 regulate the provisions concerning electromagnetic radiation, measurement methods and their norms. Whereas the directive 2004/40/EC as of 29 April 2004 on minimum requirements is concerned with the security and health protection of workers subjected to an exposure to electromagnetic fields. The Polish Central Office of Measures has generated a group of PN ISO documents containing norms regarding harmful working environments and hygiene conditions and defining what constitutes excessive levels. Sanitary factors are specified by art. 20a of the act of 14 March 1985 of National Sanitary Inspection (i.e. Journal of Laws of 2011 No. 212, it. 1263, as amended) and the regulation of the Minister of National Defence as of 14 June 2002 (with regard to organisation and methods of performing tasks by Military Sanitary Inspection (JL.02.97.872)).

\section{HAZARDS}

The examination of harmful conditions of a working environment encompasses the control of the level of exposure to:

- noise

- electromagnetic radiation,

- mechanical vibrations,

- chemical agents.
Noise: with low sound A levels (solmization) above ca. $55 \mathrm{~dB}$ we observe: complaints about noise occurring in intellectual work stations, increased nervous excitability, constant irritation, as well as intellectual difficulties expressed in memory problems, an inability to focus attention, and an impeded ability to assimilate fresh information; in the case of higher sound A levels (up to ca. $75 \mathrm{~dB}$ ) noise works mainly as a stressor, which may cause violation of the system of biological balance, moreover this type of noise hinders sound reception and identification (e.g. communication), prolonged exposure to high levels of sound A (above $80 \mathrm{~dB}$ ) may cause hearing impairment. In the case of very high levels of sound A (above $115 \mathrm{~dB}$ ), noise may lead to hearing impairment even with very short exposure times [2,3].

In the initial period of exposure, high-intensity noise induces a permanent loss of ability to hear quieter sounds, and in later periods occupational deafness manifested as an inability to hear loud sounds, e.g. speech. Initial symptoms of an excessive exposure to noise include fatigue, difficulty in focusing attention, orientation disturbances, irritability, increased blood pressure, headache and vertigo, temporary or permanent hearing impairment, and tinnitus.

A long-term exposure to noise may also manifest itself in system and organ disorders. Possible side-effects include arterial hypertension, cardiac dysrhythmia, moderate anaemia, elevated $\mathrm{OB}$ and eosinophilia, increased gastric secretion, hyperactivity of adrenal glands, hyperthyroidism, increase in intracranial pressure, changes in EEG curve, weariness, irritation, quarrelsomeness, anxiety and fear, attention impairment, disturbances and difficulties to have a complete and peaceful rest and sleep. Problems with sleep also seem logical $[2,3,4,5,6]$.

In people exposed to general vibration we observe changes in the motion system, central and peripheral nervous system, impairment of sensory organs (balance, hearing, sight), as well as disturbances of the alimentary tract and, in females, in the reproductive system.

Mechanical vibrations are low-frequency acoustic vibrations spreading through solids and transmitted to a worker's organism through a part of his body that remains in direct contact with a vibrating object (source of vibration). in other words, vibration is a physical phenomenon characterised by oscillations of material points depending on their acceleration and frequency.

Vibration white finger is a syndrome encompassing non-specific changes in the vascular, nervous, and osteo-articular systems caused by the impact of mechanical vibrations on a human organism. The source of vibration may be general or local. Local sources are related to working with power tools such as a drill or a pneumatic hammer, whereas general sources include different means of transport. The period which needs to elapse from an occurrence of initial symptoms to the diagnosis of vibration white finger extends from 1 to 3 years $[7,8]$.

The chemical agents examined by WOMP as a hazard to a working environment are gasoline and carbon dioxide. Inhalation of dangerous chemical substances constitutes the most common type of an exposure in occupational conditions [9].

The symptoms of gasoline poisoning resemble typical toxicological symptoms. These include gastro- 
intestinal, vascular symptoms, damage to skin, and mucous membranes. Inhalation of dangerous chemical substances constitutes the most common type of an exposure in occupational conditions $[10,11]$.

Onboard a vessel, the radio transmitters and receivers are the main source of electromagnetic radiation. An elevated risk of leukaemia is observed in both radio amateurs and military personnel involved in operating radio communication equipment. It is also suspected that magnetic field networks don't just act as carcinogens to the human organism, but may cause other forms of harm e.g. on the central nervous system amyotrophic lateral sclerosis and Alzheimer disease, whilst from the cardiovascular system we see increased risk of death due to arrhythmia or myocardial infarction, an increase in the percentage of individuals with an elevated arterial pressure and disturbed day-night blood pressure regulation, and an increase in the risk of a disturbance of heart rhythm disorders or reproductive functions. Dermatological symptoms include skin redness, tingling sensation on the surface of the skin, and a localised sensation of warmth or overheating [12].

Others factors which are undoubtedly present in the environment of a submersible vessel are microorganisms. Among them there are such bacteria as Legionella, Pseudomonas and E. coli. The bacteria species examined by WOMP colonise ventilation shafts, water pipelines and lavatories. A closed-circulation system transmits droplets carrying bacteria which go on to colonise the airways and skin; bacteria from the group of streptococci and staphylococci. These bacteria mainly colonise the airways. Some of them may produce skin inflammation or be the cause of complications after an injury.

Preventive measures include the testing of water intended for consumption on board. Seafarers are ensured an unrestricted access to running water due to desalinating systems, however, the requirement to maintain silence in the course of the submarine's movement imposes bathing prohibitions. Due to hygiene reasons, the only person that is allowed to shower on a daily basis is the cook.

Water tests are performed with regard to its physiochemical and biological properties.

The most important part of water purity tests, from the diagnostic point of view, is the test for Escherichia Coli. In sanitary water and food examinations, it is treated as bacteria indicative of faecal contamination, and the possible presence of pathogenic micro-organisms. The presence of at just one single bacteria in potable water is perceived as an indicator of faecal contamination and water is deemed unfit for consumption. Escherichia Coli is an ubiquitous micro-organism. It is chronically present in the large intestine of a healthy person. Its pathogenic strains are enterotoxins (ETEC) responsible for travellers' diarrhoea, the enterohaemolytic strain (EHEC) causing haemorrhagic diarrhoea and haemolytic uraemic syndrome, and the enteropathogenic strains (EPEC) being responsible for diarrhoea. Gram-positive enterococcus bacteria belonging to the group of Streptococci (E. Faecalis and E. Faecium subspecies) are natural constituents of the bacterial flora of the intestines and oral cavity. These bacteria are characterised by low pathogenicity and are responsible for inducing opportunistic infections, urinary infections and endocarditis $[13,14]$.

Pseudomonas aeruginosa is a gram-negative bacillus capable of pigment production, primarily aerobic but capable of growing in anaerobic conditions. The risk of infection in the case of seafarers of a submersible vessel occurs during immunity disturbances following injuries such as burns, whereas for the general population those enduring tumours, neutropenia, diabetes, or the insertion of catheters and endotracheal tubes are at risk. The bacteria causes inflammation of airways, skin, soft tissues, urinary tract and the outer ear $[13,14]$.

\section{Preventive Measures}

Sanitary supervision is responsible for physiochemical and biological water testing, control of vaccination and medical care of seafarers, equipment and medical supplies storage, condition and access to lavatories and food storage facilities.

Noise emission measurement methods in working stations are specified by PN-N-01307:1994. The quantities which define noise with regard to hearing protection include: - noise exposure levels referring to an 8-hour working time and the corresponding daily exposure, or a noise emission level referring to weekly working times and their corresponding exposure, maximum sound A level, - sound C peak level (solmization) [13].

In this case, the following levels are determined for each activity occurring during the time of work: weighted sound A level, - maximum A sound level, - peak $\mathrm{C}$ sound level during a 30-minute exposure. The assessment of noise exposure is conducted by comparing values, which define the noise level at a working station, with allowable values provided in the aforementioned regulations (tab.1) $[13,14]$.

Onboard a vessel, along with an intensification of a chronic acoustic injury we observe the synergistic action of harmful chemical compounds (organic solvents, heavy metals, gases, pesticides) [6].

Noise level was evaluated with the use of a Svan 945 analyser by measuring the maximum sound A level norm of $115 \mathrm{~dB}$; Maximum sound A level in the period of 8 hours LA max - norm up to $80 \mathrm{~dB} / 8 \mathrm{~h}$; Peak sound C level C Lc peak up to $135 \mathrm{~dB}$. 
Noise level in particular working stations.

\begin{tabular}{llll}
\hline Position & Lex8h & Lamax & Lcpeak \\
\hline Commander & 56.5 & 63.2 & 91.9 \\
\hline Deputy commander & 56.5 & 63.2 & 91.9 \\
\hline Chief petty officer & 56.5 & 63.2 & 91.9 \\
\hline Operational sector commander & 56.5 & 63.2 & 91.9 \\
\hline Navigation division commander & 56.5 & 63.2 & 91.9 \\
\hline Junior technician of the navigation department & 56.5 & 63.2 & 91.9 \\
\hline Underwater weapons division commander & 56.5 & 63.2 & 91.9 \\
\hline Junior technician of underwater weapons division & 56.5 & 63.2 & 91.9 \\
\hline Communications division commander & 56.5 & 63.2 & 91.9 \\
\hline Senior operator of hydroacoustic group & 56.5 & 63.2 & 91.9 \\
\hline Junior operator of hydroacoustic group & 56.5 & 63.2 & 91.9 \\
\hline Consumables division commander & 99.5 & 118.3 & 134.4 \\
\hline Senior technician of main propulsion division & 99.5 & 118.3 & 134.4 \\
\hline Independent operator of main propulsion division & 99.5 & 118.3 & 134.4 \\
\hline Electromagnetic division commander & 99.5 & 118.3 & 134.4 \\
\hline Electromagnetic division technician & 78.1 & 85.3 & 105.3 \\
\hline Independently operator of electromagnetic division & 78.1 & 85.3 & 105.3 \\
\hline Senior operator of electromagnetic division & 78.1 & 85.3 & 105.3 \\
\hline
\end{tabular}

Exceeded limits were noted in the case of the working stations of consumables division commander, senior technician of main propulsion division, independent operator of main propulsion division, electromagnetic division commander.

Mechanical vibrations were estimated with the use of mechanical vibration meter SVAN SV 106 with SV
$38 \mathrm{~V}$ vibration transducer. The corrected values of vibration acceleration in $\mathrm{x}, \mathrm{y}, \mathrm{z}$ directions are the basis in the determination of sums of vector vibration acceleration (fig. 1). The measurements are contained in table 2 .

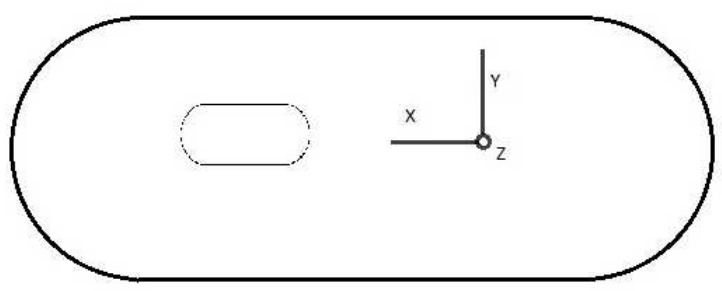

Fig. 1. Mechanical vibration deflection curve with regard to the vessel's directions.

In a 30-minute exposure the intensity of mechanical vibrations should not exceed $3.2 \mathrm{~m} / \mathrm{s}^{2}$. Thus, mechanical vibrations do not pose a health hazards for seafarers. 
Acceleration of material points in different directions in relation to the vessel (with reference to figure 1).

\begin{tabular}{|c|c|c|}
\hline Commander & $\mathrm{x}$ & 0.0044 \\
\hline & $\mathrm{y}$ & 0.0066 \\
\hline & $\mathrm{z}$ & 0.0126 \\
\hline \multirow[t]{3}{*}{ Deputy commander } & $\mathrm{x}$ & 0.0044 \\
\hline & $\mathrm{y}$ & 0.0066 \\
\hline & $\mathrm{z}$ & 0.0126 \\
\hline \multirow[t]{3}{*}{ Chief petty officer } & $\mathrm{x}$ & 0.0044 \\
\hline & $\mathrm{y}$ & 0.0066 \\
\hline & $\mathrm{z}$ & 0.0126 \\
\hline \multirow[t]{3}{*}{ Operational sector commander } & $\mathrm{x}$ & 0.0044 \\
\hline & $\mathrm{y}$ & 0.0066 \\
\hline & $\mathrm{z}$ & 0.0126 \\
\hline \multirow[t]{3}{*}{ Navigation division commander } & $\mathrm{x}$ & 0.0044 \\
\hline & $\mathrm{y}$ & 0.0066 \\
\hline & $\mathrm{z}$ & 0.0126 \\
\hline \multirow[t]{3}{*}{ Junior technician of the navigation department } & $\mathrm{x}$ & 0.0044 \\
\hline & $\mathrm{y}$ & 0.0066 \\
\hline & $\mathrm{z}$ & 0.0126 \\
\hline \multirow[t]{3}{*}{ Underwater weapons division commander } & $\mathrm{x}$ & 0.0044 \\
\hline & $\mathrm{y}$ & 0.0066 \\
\hline & $\mathrm{z}$ & 0.0126 \\
\hline \multirow[t]{3}{*}{ Junior technician of underwater weapons division } & $\mathrm{x}$ & 0.0044 \\
\hline & $\mathrm{y}$ & 0.0066 \\
\hline & $\mathrm{z}$ & 0.0126 \\
\hline \multirow[t]{3}{*}{ Communications division commander } & $\mathrm{x}$ & 0.0044 \\
\hline & $\mathrm{y}$ & 0.0066 \\
\hline & $\mathrm{z}$ & 0.0126 \\
\hline \multirow[t]{3}{*}{ Senior operator of hydroacoustic group } & $\mathrm{x}$ & 0.0044 \\
\hline & $\mathrm{y}$ & 0.0066 \\
\hline & $\mathrm{z}$ & 0.0126 \\
\hline \multirow[t]{3}{*}{ Junior operator of group e } & $\mathrm{x}$ & 0.0044 \\
\hline & $\mathrm{y}$ & 0.0066 \\
\hline & $\mathrm{z}$ & 0.0126 \\
\hline \multirow[t]{3}{*}{ Consumables division commander } & $\mathrm{x}$ & 0.0044 \\
\hline & $\mathrm{y}$ & 0.0066 \\
\hline & $\mathrm{z}$ & 0.0126 \\
\hline \multirow[t]{3}{*}{ Senior technician of main propulsion division } & $\mathrm{x}$ & 0.0044 \\
\hline & $\mathrm{y}$ & 0.0066 \\
\hline & $\mathrm{z}$ & 0.0126 \\
\hline \multirow[t]{3}{*}{ Independent operator of main propulsion division } & $\mathrm{x}$ & 0.0044 \\
\hline & $\mathrm{y}$ & 0.0066 \\
\hline & $\mathrm{z}$ & 0.0126 \\
\hline
\end{tabular}


Acceleration of material points in different directions in relation to the vessel (with reference to figure 1).

\begin{tabular}{lcc}
\hline Electromagnetic division commander & $\mathrm{x}$ & 0.0044 \\
\hline & $\mathrm{y}$ & 0.0066 \\
\hline Electromagnetic division technician & $\mathrm{z}$ & 0.0126 \\
\hline & $\mathrm{x}$ & 0.0044 \\
\hline Independent operator of electromagnetic division & $\mathrm{y}$ & 0.0066 \\
\hline & $\mathrm{z}$ & 0.0126 \\
\hline & $\mathrm{x}$ & 0.0044 \\
\hline Senior operator of electromagnetic division & $\mathrm{y}$ & 0.0066 \\
\hline & $\mathrm{z}$ & 0.0126 \\
\hline & $\mathrm{x}$ & 0.0044 \\
\hline & $\mathrm{y}$ & 0.0066 \\
\hline
\end{tabular}

Chemical agent measurements were performed with the use of a Two-met Drager device with CMS aspirator. It examined gasoline and carbon monoxide levels in the atmosphere. Measurement results are presented in table 3 .

The concentration of chemical agents in vessel' atmosphere NDS - highest allowable concentration.

\begin{tabular}{cccc} 
& NDS & Temporary NDS & Measurement \\
\hline gasoline & 300 & 900 & 20.3 \\
\hline CO & 23 & 117 & 1.43 \\
\hline $\mathrm{mg} / \mathrm{m}^{3}$ & & & \\
\hline
\end{tabular}

Electromagnetic radiation measurements indicate a hazard zone up to $25 \mathrm{~cm}$ from XK-2100L and RT1217 V5 radio station masts - ca. $25(\mathrm{~A} / \mathrm{m})^{2} \mathrm{~h}, 0.25$ $(\mathrm{V} / \mathrm{m})^{2} \mathrm{~h}$ with allowable doses (results are presented in table 4.):

Allowable emission dose for magnetic radiation [E] $20.48(\mathrm{~A} / \mathrm{m})^{2} \mathrm{~h}$.

Allowable emission dose for electric radiation [H] $0.053(\mathrm{~V} / \mathrm{m})^{2} \mathrm{~h}$.

Electromagnetic radiation level in particular working stations

\begin{tabular}{lll} 
Measurement line & $\mathrm{E}$ & $\mathrm{H}$ \\
\hline Operator & 3 & 0.008 \\
\hline Helmsman & 3 & 0.008 \\
\hline Radar operator & 3 & 0.008 \\
\hline Engineer Officer & 3 & 0.008 \\
\hline Navigator & 2 & 0.0053 \\
\hline Operator & 3 & 0.008 \\
\hline Electrician & 2 & 0.0053 \\
\hline Motorman & 4 & 0.0107 \\
\hline Watch Officer & 16 & 0.042 \\
\hline Mess & 1 & 0.0026 \\
\hline
\end{tabular}




\begin{tabular}{lll}
\hline Head office bow & 2 & 0.0053 \\
\hline Head office stern & 2 & 0.0053 \\
\hline Power plant & 3 & 0.008 \\
\hline $15 \mathrm{~cm}$ from XK-2100L/I antenna mast & 20 & 0.053 \\
\hline $15 \mathrm{~cm}$ from XK-2100L/II antenna mast & 25 & 0.066 \\
\hline 15cm from RT-1217V antenna mast & 98 & 0.26 \\
\hline Decm from RT 1217V antenna mast & 65 & 0.017 \\
\hline
\end{tabular}

The watch officer's position is characterised by the highest radiation dose; however it does not exceed the specified limit. Bacteriological water testing allows determination of total bacteria count as well as quantities of particular bacteria species. These include Coli, E. Coli, Enterococci and Pseudomonas aeruginosa. (tab. 5).

Bacteria colonies count in water sample.

\begin{tabular}{cc}
\hline Water quality index & bacteria count \\
\hline total bacteria count $\left(36^{\circ} \mathrm{C}, 48 \mathrm{~h}\right)$ & 27 \\
\hline Coliform bacteria & 0 \\
\hline E. coli & 0 \\
\hline Enterococci & 0 \\
\hline Pseudomonas Aeroginosa & 0 \\
\hline colony count $\left(22^{\circ} \mathrm{C}, 72 \mathrm{~h}\right)$ & $>300$ \\
\hline
\end{tabular}

Additionally, tests are conducted with regard to bacteria colonies present on kitchenware (tab. 6).

Bacterial colonies on kitchenware (norm up to $100 \mathrm{cfu}$ ).

\begin{tabular}{lll}
\hline Tested element & $\begin{array}{l}\text { Total number of micro- } \\
\text { organisms }\end{array}$ & \\
\hline soup plate & $4 \mathrm{cfu}$ \\
\hline dinner plate & $5 \mathrm{cfu}$ \\
\hline red knife & $>100 \mathrm{cfu}$ \\
\hline green knife & $3 \mathrm{cfu}$ \\
\hline dessert plate & $1 \mathrm{cfu}$ \\
\hline dinner plate & $2 \mathrm{cfu}$ \\
\hline yellow knife & $2 \mathrm{cfu}$ \\
\hline consomme dish & $2 \mathrm{cfu}$ \\
\hline brown knife & $>100 \mathrm{cfu}$ \\
\hline dessert plate & $7 \mathrm{cfu}$ \\
\hline
\end{tabular}

\section{DISCUSSION OF RESULTS}

A submersible vessel is an environment of an increased risk of an occurrence of infectious and occupational diseases.

The conducted tests, with regard to occupational exposure, define noise emission as the most harmful condition in this working environment. The risk of an occurrence of occupational diseases in particular working stations is reduced by the use of hearing protection. There exists an elevated level of exposure to electromagnetic radiation. Mechanical vibrations constitute a factor which does not pose a threat to seafarers with regard to their health.

What is worth considering is a colony growth test. Improper disinfection may lead to the spread of infectious diseases in the alimentary tract, resulting from the growth of other colonies than those tested, which 
should convince seafarers of submersible vessels to strictly observe hygiene regulations.

It is necessary to conduct distant tests concerning the effect of the conditions of the working environment and hygiene on seafarers' health status upon service completion, as well as concerning the seafarers' attitude to service and its effect on them. It is a fact that seafarers' state of health requires systematic monitoring.

\section{ConCluSions}

The exceeding of noise emission limits were noted in the working stations of the consumables division commander, senior technician of main propulsion division, independent operator of main propulsion division and electromagnetic division commander.
The highest radiation level, on the other hand, was observed in the watch officer's station located nearest to the radio station masts. Along with distance reduction, the level of exposure grows.

With consideration to the health status of seafarers, submersible vessels create a moderately high risk. It is necessary to regularly examine seafarers and implement long-term preventive and treatment programmes evaluating their health conditions upon service completion.

\section{BIBLIOGRAPHY}

1. Kimhi S. Understanding Good Coping: A Submarine Crew Coping with Extreme Environmental Conditions, Psychology 2011. Vol.2, No.9, 961967 DOI:10.4236/psych.2011.29145;

2. Marczak P. Wybrane zagadnienia Opracowania tematyczne OT-612, 2012 [Selected issues];

3. Rozporządzenie Ministra Pracy i Polityki Socjalnej w sprawie ogólnych przepisów bezpieczeństwa i higieny pracy z 26 września $1997 r$. (Dz.U. Nr 129 z 1997r Poz.844) PNN-01307:1994. Hałas. Dopuszczalne wartości hałasu w środowisku pracy. Wymagania dotyczace wykonywania pomiarów. [Minister of Labour and Social Policy on general safety and hygiene regulation, September 26, 1997. (Journal of Laws No. 129 of 1997 it. 844) PNN-01307: 1994. Noise. Permissible values of noise in the workplace. Requirements for measurement.];

4. Mikulski W. Ochrona przed hałasem, CIOP BIP, Puławy 2005, http://docplayer.pl/10470478-Dr-inz-witold-mikulski.html [quoted on 29.09.2016]; PE-EN -ISO PN-N-01307:1994

6. Gryczyński M. Latkowski B. Choroby z zakresu otolaryngologii w praktyce lekarza rodzinnego. in: Medycyna Rodzinna Latkowski B, Lukas W, Warszawa 2009 [Disease in otolaryngology in general practice];

7. Informacje ogólne, Centralny Ośrodek Ochrony Pracy- Państwowy Ośrodek Badawczy http://archiwum.ciop.pl/1351.html;

8. Stasiów B. Problemy diagnostyczne postaci kostno-stawowej zespołu wibracyjnego, Medycyna Pracy, Łódź 2001;52; 2; 139-144. [Diagnostic problems as osteo-articular aspect of vibration syndrome];

9. Grausz T. Zagrożenia czynnikami chemicznymi w miejscu pracy Państwowa Inspekcja Pracy, Główny Inspektorat Pracy Warszawa 2013 https://www.pip.gov.pl/pl/f/v/97391/br-chemiczne-zagroz.pdf [quoted on 10.10.2016];

10. Sowa M. Winnicki A. Wójcik K. Tarkowski M. Gnatowski T. Carbon monoxide poisoning - the route of exposure, clinical symptoms, treatment Formerly Journal of Health Sciences. ISSN 1429-9623 / 2300-665X. Archives $2011-2014$

11. Grausz T. Zagrożenia czynnikami chemicznymi w miejscu pracy, 09001/02/00 Warsaw 2013[Threats to chemical factors at work];

12. Zmyślony M. Politański P. Zagrożenie zdrowia i ochrona zdrowia pracujących w narażeniu na pola magnetyczne $0-300 \mathrm{GHz}$, Instytut Medycyny Pracy im. prof. J. Nofera, Łódź 2009, 25-40, ISBN 978-83-60818-38-1, [Damage to health and health care workers in exposure to magnetic fields $0-300 \mathrm{GHz}$ ]

13. Virella G. Mikrobiologia i choroby zakaźne, Urban \& Partner, Wrocław 2000, dodruk 2009, ISBN 978-83-85842-59-0 [Microbiology and infectious diseases];

14. P. Heczko, M. Wróblewska, A. Pietrzyk Mikrobiologia lekarska PZWL, Warszawa 2015, [Medical Microbiology].

\section{lek. med. Michał Żychliński}

Maritime and Hyperbaric Medicine Department

Military Institute of Medicine

ul. Kmdr Grudzińskiego 4 81-103 Gdynia

zychlinskimichal@gmail.com, tel. 691363199 